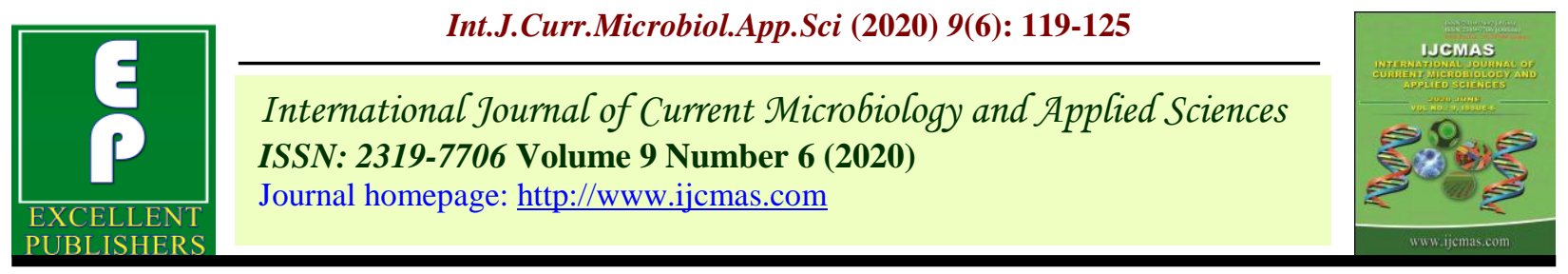

\title{
Impact of Inclined Solar Drier for Dehydration Quality in Khadrawy Dates during Doka Maturity Stage at North Western Arid India
}

\author{
Julius Uchoi ${ }^{1^{*}}$, Prashant H. Nikhumbhe ${ }^{2}$, Abhishek Kumar ${ }^{3}$, \\ Anil Patidar ${ }^{3}$ and G. D. Harish ${ }^{1}$ \\ ${ }^{1}$ ICAR-National Bureau of Plant Genetic Resources, Regional Station, Shillong-793103, India \\ ${ }^{2}$ ICAR-Central Arid Zone Research Institute, Jodhpur-342003, India \\ ${ }^{3}$ ICAR-Central Arid Zone Research Institute, Regional Research Station, \\ Jaisalmer-345001, India \\ *Corresponding author
}

\section{A B S T R A C T}

Keywords

Date palm fruits, post-harvest, solar dehydration

Article Info

Accepted:

12 May 2020

Available Online:

10 June 2020
Experiment conducted on post-harvest utilization of date palm fruits of cultivar Khadrawy at doka maturity stage for development of dehydrated fruits at three different duration of days i.e. 5, 7 and 9days through inclined solar drier revealed that solar dehydration of the whole date fruits with increased duration of nine days led to the development of the dehydrated product with significant different for minimum physiological loss in weight $(46.2 \%)$ and maximum recovery percentage (53.8\%). However, on biochemical parameter the retention of quality of total sugar $(52.1 \%)$, reducing sugar $(2.7 \%)$ and Non reducing sugar $(49.3 \%)$ was found significantly different when fruits were dried with minimum duration for five days. Organoleptic test by hedonic scoring revealed that the average scoring by the panels ranged from like slightly (6) to like very much (8) for color, flavour, texture and taste in the dehydrated fruits.

\section{Introduction}

Date Palm (Phoenix dactylifera L.) being classified as non-climacteric fruit is one of the oldest fruit trees in the world and are considered to be nutritious and a high-energy food (300 calories/100 g) due to rich in sugars providing quick energy intake (Sawaya et al., 1982, Booji et al., 1992, Ahmed et al., 1995), minerals (Imad and Abdul Wahab 1995, Hafid et al., 2007, Elleuch et al., 2008), vitamins, phenols, flavonoids, anthocyanins and carotenoids with functional properties (AlFarsi et al., 2005a, Hafidetal.2007, Biglari et al., 2008, Al-Turkietal, 2010).

The soluble fiber helps against constipation (Kulkarni et al., 2008), and the low level of fat high in omega-3, omega 6, and oleic acid, is heart-healthy. In international market fresh dates are typically marketed at three of the four stages of its growth and development 
(Khalal, Rutab and Tamar) and can be consumed soft, semi-dry or as dry fruits, depending on their water content at harvest when fully-ripe, or in various processed forms (Sawaya 1986). In India increasing trend of dates consumption is evident from the report of being leading importer (FAO). Favorable soil and dry climatic conditions led to progressive cultivation of this fruit crops excepting the pattern of rainfall distribution. In Indian conditions among the date palm cultivars Khadrawy is one of the important astringent date palm cultivars grown commercially especially in north western region of the country and very suitable for consumption after converting into chuhara (dry) form. During the onset of maturity starting from doka stage, India subcontinent received south western showers unlike the traditional growing countries where the fruits can be ripened at the palm itself due to absence of rain during this period. So receiving rainfall during doka stage or dang stage(half ripening stage) create humidity giving chance for fungal growth which deteriorate the quality of fruits by pathogenic invasion mostly by coliforms and faecal coliforms (Al-hooti et al., 2002) and also deposition of dust particles on the fruits surface, which leads to loss of economic return. Moreover, due to astringent in taste at doka stage. This cultivar is not suitable to consume at this stage. Traditional open sundrying though is practiced but it face challenges of its market potential as export due to adherence of sand dust particles. In view of this, possible intervention as low cost non energy structures for utilization of this fruits through dehydration by inclined solar drier for its physical and biochemical parameters are undertaken for its quality.

\section{Materials and Methods}

The experimental material i.e. Khadrawy date fruits at physiologically mature stage called doka was harvested during the month of July from Date palm research centre, Bhojka farm, Jaisalmer. The fruits was thoroughly washed with running tap water to removed dust and other pathogens. The washed fruits were dehydrated as whole fruits and only pulp under low cost inclined solar dryer developed by ICAR- Central Arid zone research institute, Jodhpur with eight treatments consisting for a duration of five, seven and nine days including control where fruits are dried under open sun drying (T1- solar dehydration of the whole fruits for 5days, T2solar dehydration of only pulp for 5days, T3solar dehydration of whole fruits for 7 days, T4- solar dehydration of only pulp for 7days, T5- solar dehydration of whole fruits for 9days, T6- solar dehydration of only pulp for 9days, T7(control)-open sun drying of whole fruits for 9days and T8(control)- open sun drying of only pulp for 9days. In each replication, thirty fruits were allocated for observation. The designed used for experimental study was completely randomized design with three replications. Physical parameters (physiological loss in weight, percent recovery), Biochemical parameter (Total sugars, Reducing sugars and Non reducing sugar) and organoleptic test were recorded, conducted and analysed.

\section{Physiological loss in weight}

Physiological loss in weight (\%) Four fruits from each treatment were weighed on first day of treatment and subsequently their weight was recorded at six day interval up to the end of shelf life. The physiological loss in weight (PLW) was expressed in percentage and calculated as follows. PLW $\%=\mathrm{W} 1-$ W2/ W1 X 100 Where, W1 = initial weight and W2 =final weight (Shankar et al., 2009) Physiological loss in weight (PLW) were calculated as: Initial fresh weight - Final dry weight/ Initial weight x 100 and expressed in percentage. 


\section{Recovery percentage (\%)}

For recovery percentage, the fresh weight and final dry weight of the product were recorded and on this basis, recovery percentage (RP) is determined as: Recovery percentage $(\%)=$ Final dry weight / Initial fresh weight x 100 . In biochemical parameter estimation.

\section{Total sugar $(\%)$}

Total sugar was determined by the method described by Dubois et al., (1951). Reducing sugar (\%): Reducing sugar by the method analysed by Nelson modifications of Somogyi method (Somogyi, 1952). Non reducing sugars were obtained by subtracting reducing sugars from total sugars.

\section{Organoleptic test}

The dehydrated fruits were sensory evaluated for four parameter such as color, flavour, texture and taste by member jury based on nine point hedonic score (9-like extremely, 8like very much, 7-like moderately, 6-like slightly, 5-neither like nor dislike,4-dislike slightly, 3-dislike moderately, 2-dislike very much,1-dislike extremely) (Peryam and Pilgrim 1957). The data were subjected to one ANOVA and significant among the treatment mean at 5\% level analysed by the method described by Gomez and Gomez (1984).

\section{Results and Discussion}

\section{Physiological loss in weight}

Significant effect has been observed due to the different duration of days on the impact of Physiological loss in weight(PLW\%) when fruits are either dried whole or only pulps as compared to open sun drying. The result shows decreasing trend of the physiological loss in weight in the dried fruit product when both either as a whole fruit or only pulp was dried under solar drier (Table 1). The lowest minimum physiological loss in weight was recorded when whole fruits were dried for duration of nine days (46.2\%) followed by seven days $(47.8 \%)$.

It was found that physiological loss in weight in dried pulp was more when compared to drying of only whole fruits. The increase in PLW (\%) in pulp may be attributed due to non-intact of the seeds and more respiration from the surfaces as compared to the whole dried fruits. With the increase in duration of drying days the fruits weight loss was minimum in solar dehydration when compared to the open sundrying.

This finding was contrary to the earlier work done by Lovejoy et al., 2008. The lost of more fruit weight in open sun drying as control compared to dehydration under inclined solar drier may be due to faster wind velocity which enables it to sweeps away the stagnant boundary layer of air around the moist surface.

Therefore when there is increase in the air velocity, it affects the drying time significantly by aiding the drying of stagnant boundary (Mecer et al., 2012). This finding is similar to work reported by Felix et al., (2018).

\section{Percent recovery}

As revealed from the table 1. The results revealed that there was a significant effect of the duration of drying on the percent recovery of Khadrawy dates fruits. Highest per cent recovery $(53.8 \%)$ was obtained when the whole fruits dried inside the inclined solar drier for nine days followed by seven days $(52.2 \%)$. It clearly revealed that as physiological loss in weight in inversely related to the percent recovery of the dried 
product, minimum physiological loss in weight leads to higher per cent recovery and product with higher per cent recovery without loss of quality is desirable. The long drying time as well as high temperature can reduce the product quality due to caramelisation, Maillard reactions, enzymatic reactions, pigment degradation, and L-ascorbic acid oxidation (Arslan and Özcan, 2011).

This increased retention in per cent recovery may be due to the intact of the pulp attached to the seeds and the relative loss of moisture from the fruits surface may be less as compared to the exposure of only pulp even though this may be due to the solar drying effect inside the solar dryer where the temperature inside the dyer keeps on increasing with decrease in relative humidity inside the dryer (Heba et al., 2019).

\section{Biochemical parameters}

Analysis on biochemical parameter pertaining to total sugar, reducing sugar and nonreducing sugar of the solar dehydrated cultivar of Khadrawy revealed significant different among the treatments.

It revealed that when whole fruits were solar dried for the minimum duration of the treatment the biochemical parameter for total sugar $(52.1 \%)$, reducing sugar(2.7\%) and Non reducing sugar(49.3\%) were found to be higher when whole fruits are dried for five days. This finding were in confirmation with that of Sagar and Kumar (2006) and Prajapati et al., (2011) in dried aonla shreds and Vijayanand et al., (2007) in dehydrated aonla powder where solar drier have impact on increase in total sugar content.

Table.1 Effect of inclined solar drier on physiological loss in weight and percent recovery on Khadrawy dates fruits

\begin{tabular}{|l|c|c|c|c|c|}
\hline & \multicolumn{3}{|c|}{ Physical parameters } & \multicolumn{3}{c|}{ Biochemical parameters } \\
\hline Treatments & PLW (\%) & PR(\%) & TS(\%) & RS(\%) & NRS(\%) \\
\hline $\mathbf{T}_{\mathbf{1}}$ & 50.4 & 49.6 & 52.1 & 2.7 & 49.3 \\
\hline $\mathbf{T}_{\mathbf{2}}$ & 53.4 & 46.6 & 43.4 & 2.8 & 40.6 \\
\hline $\mathbf{T}_{\mathbf{3}}$ & 47.8 & 52.2 & 51.2 & 2.1 & 49.1 \\
\hline $\mathbf{T}_{\mathbf{4}}$ & 50.6 & 49.4 & 45.6 & 1.9 & 43.7 \\
\hline $\mathbf{T}_{\mathbf{5}}$ & 46.2 & 53.8 & 43.3 & 1.8 & 41.5 \\
\hline $\mathbf{T}_{\mathbf{6}}$ & 51.9 & 48.1 & 42.3 & 1.9 & 40.4 \\
\hline $\mathbf{T}_{\mathbf{7}}$ & 51.8 & 48.2 & 45.2 & 1.5 & 43.7 \\
\hline $\mathbf{T}_{\mathbf{8}}$ & 62.6 & 37.4 & 44.7 & 1.3 & 43.4 \\
\hline CD@5\% & 5.1 & 5.1 & 0.26 & 0.03 & 0.25 \\
\hline Significant & $*$ & $*$ & $*$ & $*$ & $*$ \\
\hline test & & & & & \\
\hline
\end{tabular}

TS- Total Sugar, RS- Reducing Sugar, NRS- Non Reducing Sugar,

PLW-Physiological loss in weight PR-Percent recovery; *- Significant 
Table.2 Sensory evaluation of organoleptic score in solar dehydrated date in Khadrawy

\begin{tabular}{|l|c|c|c|c|}
\hline \multirow{2}{*}{ Treatments } & \multicolumn{4}{|c|}{ Khadrawy } \\
\cline { 2 - 5 } & Colour & Flavour & Texture & Taste. \\
\hline T1 & 8 & 7 & 7 & 7 \\
\hline T2 & 7 & 7 & 7 & 8 \\
\hline T3 & 7 & 7 & 7 & 7 \\
\hline T4 & 6 & 7 & 7 & 7 \\
\hline T5 & 7 & 6 & 7 & 6 \\
\hline T6 & 7 & 6 & 7 & 6 \\
\hline T7 & 8 & 6 & 7 & 7 \\
\hline T8 & 7 & 6 & 7 & 6 \\
\hline
\end{tabular}

(9-like extremely,8-like very much,7-like moderately,6-like slightly,5-neither like nor dislike,4-dislike slightly,3dislike moderately,2-dislike very much,1-dislike extremely

$\mathrm{T}_{1}$ - Solar dehydration of the whole fruits for 5 days, $\mathrm{T}_{2}$ - Solar dehydration of fruit pulp without stone for 5 days, $\mathrm{T}_{3}-$ Solar dehydration of the whole fruits for 7 days, $\mathrm{T}_{4}$ - Solar dehydration of fruit pulp without stone for 7 days, $\mathrm{T}_{5}$ Solar dehydration of the whole fruits for 9 days $\mathrm{T}_{6}$ - Solar dehydration of fruit pulp without stone for 9 days $\mathrm{T}_{7^{-}}$ Open sun drying of the whole fruits for 9 days(control) $\mathrm{T}_{8}$ - Open sun drying of the fruit pulp without stone for 9 days(control).

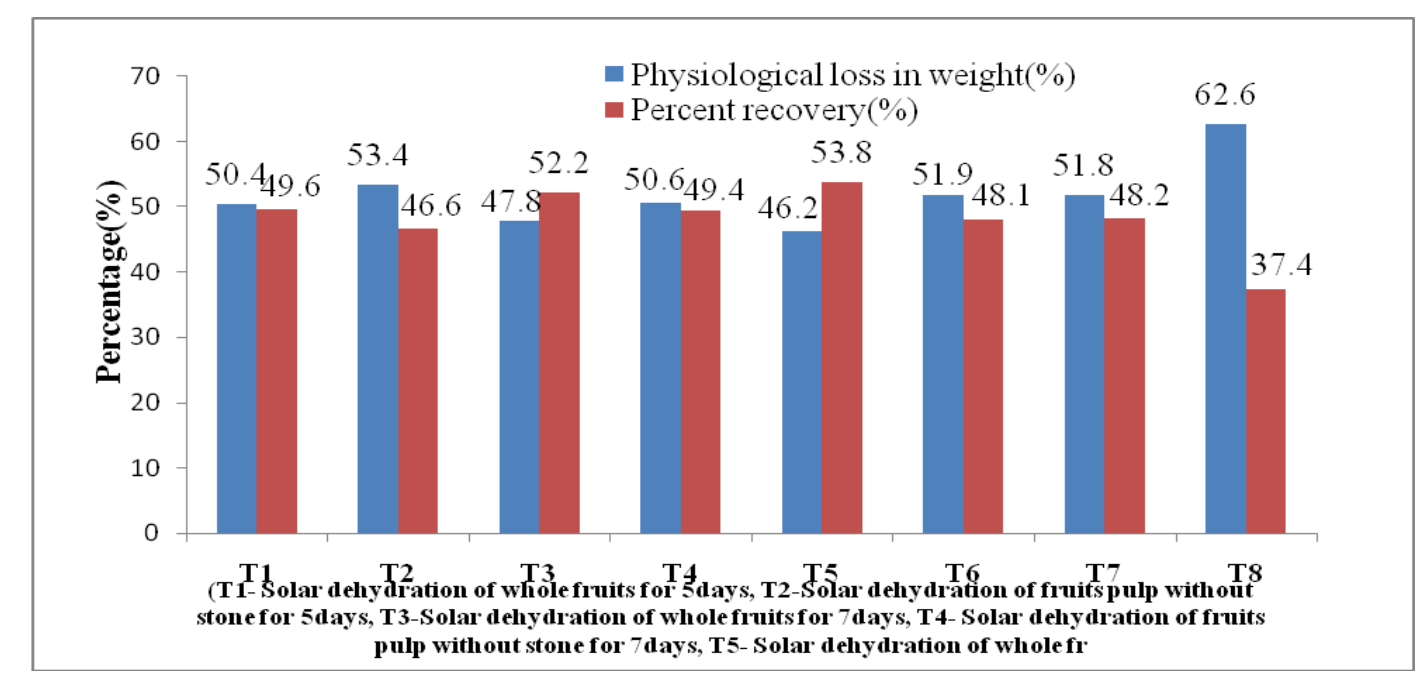

Fig.1 Trends showing the impact of solar drier on the physiological loss in weight and percent recovery $(\%)$ in khadrawy date fruits

The mean hedonic score conducted on four paramaters such as colour, flavour, texture and taste ranged from 6-8. Sensory evaluation conducted on four parameter in Khadrawy cultivar revealed that all the panel judge the color, flavor and taste from like slightly to like very much. With regards to flavour their liking was from slightly to moderately. However for texture their liking was all moderately indicating the texture does not varies much.

\section{Acknowledgement}

Authors would like to thank Director, ICARCAZRI, Jodhpur for allowing the facility to conduct research and deputy director of date palm excellency centre, Bhojka farm, Jaisalmer for providing experimental material.

\section{References}

Ahmed, I.A., Ahmed, A.W.K. and Robinson,
R.K.(1995).Chemical composition of 
date varieties as influenced by the stage of ripening. Food Chem 54: 305-09.

Al-Fars,i M., Alasalvar, C., Morris, A., Baron and M, Shahidi F. (2005). Comparison of antioxidant activity, anthocyanins, carotenoids, and phenolics of three native fresh and sundried date (Phoenix dactylifera $\mathrm{L}$.) varieties grown in Oman. J Agric Food Chem 53: 7592-9

Al-Hooti, S.N., Sidhu, J.S., Al-Saqer, J.M. and AlOthman A(2002). Chemical composition and quality of date syrup as affected by pectinase/cellulose enzyme treatment. Food Chemistry. 79(2):215220.

Al-Turki, S., Shahba, M.A. and Stushnoff, C. (2010). Diversity of antioxidant properties and phenolic content of date palm (Phoenix dactylifera L.) fruits as affected by cultivar and location. $J$ Food Agric Env 8: 253-60.

Arslan, D. and Özcan, M. M. (2010). Study the Effect of Sun, Oven and Microwave Drying on Quality of Onion Slices. LWT - Food Sci.Technol., 43(7): 11211127.

Biglari, F., AlKarkhi, A.F.M. and Azhar, M.E., (2008). Cluster analysis of antioxidant compounds in dates (Phoenix dactylifera L.): Effect of longterm cold storage. Food Chem 112: 998- 1001 .

Booji, I., Piombo, G., Risterucci, A.M., Coupm, D.T. and Ferry, M. (1992). Study of chemical composition of dates at various stages of maturity for the varietal characterization various cultivars of palm trees (Phoenix dactylifera L.). Fruits 47: 667-78.

Dubois, M., Gilies, K., Hammilton, J.K, Robers P A and Smith F A. (1951). A calorimetric method for the determination of sugars relatedsubstances. 350-356.

Elleuch M, Besbes S, Roiseux O, Blecker C, Deroanne C, Drira N, Attia H. (2008).
Date flesh: Chemical composition and characteristics of the dietary fiber. Food Chem 111: 676-82.

Felix, G. N., Cosmas, N., Anyanwu., Nicholas, O., Namessan., Andekatso, A., Ahmadu., Muhammad, A. and Suleiman.(2018). An Overview of Solar Fruit Drying: A Potential Remedy for Postharvest Losses in Nigeria. International Research Journal of Engineering and Technology (IRJET). 05(04): 3559-3568.

Hafid B., Panagistis K. and Damaso-Horner M. (2007). Carotenoid composition of Algerian date fruits at edible maturation stage. Food Chem 101: 1372-7.

Heba, A. M.,. Abd El-Rahmam, A. A and Hassan, H. E. (2019). Drying of tomato fruits using solar energy. AgricEngInt: CIGR Journal Open access at http://www.cigrjournal.org. 21(2): 204215.

Imad AA, Abdul Wahab KA. (1995). Chemical composition of date varieties as influenced by the stage of ripening. $\mathrm{J}$ Food Chem 54: 305-09.

Kulkarni SG, Vijayanand P, Aksha M, Reena P. and Ramana, K.V.R. (2008). Effect of dehydration on the quality and storage stability of immature dates (Pheonix dactylifera). Food Sci Technol 41: 278-83.

Lovejoy, T., Chiteka, Z. A., Irene, K., Festus, K., Akinnifesi. and Fanuel, Tagwira. (2008) Blanching and drying period affect moisture loss and vitamin $\mathrm{C}$ content in Ziziphus mauritiana (Lamk.). African Journal of Biotechnology Vol. 7 (8), pp. 3100-3106

Mecer, D., A Basic Guides to Drying of Fruit and Vegetable, in Department of Food Science. (2012) .University of Guelgh: Ontario, Canada. p. 28-14.

Peryam, D.R. and Pilgrim, F.J. (1957). Hedonic scale method of measuring food preferences. Food Technology 
Prajapati, V.K., Prabhat ,K., Nema. and Rathore S. S.(2011). Effect of pretreatment and drying methods on quality of value-added dried aonla (Emblica officinalis Gaertn) shreds. J Food Sci Technol (Jan-Feb 2011) 48(1):45-52. DOI 10.1007/s13197-010$0124-\mathrm{Z}$

Sagar, V.R. and Kumar, R. (2006) Preparation and storage study of ready-toeat dehydrated gooseberry (aonla) shreds. J Food Sci Technol 43:349-352

Sawaya, W.N. (1986). Date of Saudi Arabia. Riyadh: KSA Safer Press. pp 75-87.

Sawaya, W.N., Khatchadourian, H.A., Khalil, J.K., Safi, W.M. and Shalha, T.A. (1982). Growth and compositional changes during the various development stages of some Saudi Arabian date cultivars. J Food Sci 47: 1489-92.

Shankar,V., Veeragavathatham, D. and Kannan, M. (2009). Effect of organic farming practices on post-harvest storage life and organoleptic quality of yellow onion (Allium cepa L.). Indian Journal of Agricultural Sciences, 79(8): 608-614.

Somogyi, M. (1952). Notes on sugar determination. . J. Biol. Chem 195 :(1) 19-23.

Vijayanand, P., Kulkarni, S.G., Reena, P., Aksha, M. and Ramana, K.V.R. (2007) Effect of processing on gooseberry fruits and quality changes in dehydrated gooseberry powder during storage. J Food Sci Technol 44:591-594.

\section{How to cite this article:}

Julius Uchoi, Prashant H. Nikhumbhe, Abhishek Kumar, Anil Patidar and Harish G.D. 2020. Impact of Inclined Solar Drier for Dehydration Quality in Khadrawy Dates during Doka Maturity Stage at North Western Arid India. Int.J.Curr.Microbiol.App.Sci. 9(06): 119-125. doi: https://doi.org/10.20546/ijcmas.2020.906.015 